\title{
ПРОБЛЕМИ У СФЕРІ ТЕХНІЧНОЇ ІНВЕНТАРИЗАЦІЇ ОБ'ЄКТІВ НЕРУХОМОСТІ ТА ШЛЯХИ ЇХ ВИРІШЕННЯ
}

\section{PROBLEMS IN THE FIELD OF TECHNICAL INVENTORY OF REAL ESTATE OBJECTS AND WAYS TO SOLVE THEM}

\begin{abstract}
Білошицька Н.І., к.т.н., доц., Шпарбер М.Є., ст. викл., Поркуян С.Л., ст. викл., Мирошніченко I.O., студент (Східноукраїнський національний університет імені Володимира Даля)
\end{abstract}

Biloshytska N.I., Ph.D., Associate Professor, Shparber M.E., Senior Lecturer, Porkuyan S.L., senior lecturer, Myroshnichenko I.O., student (Volodymyr Dahl East Ukrainian National University)

У роботі досліджено питання проведення технічної інвентаризації об'єктів нерухомого майна в сучасних умовах, визначено коло основних проблемних ситуацій щуодо питань проведення технічної інвентаризації, з якими має справу ринок. Запропоновано методичні підходи та шляхи їх вирішення з використанням сучасних програм та засобів автоматизованої роботи з базами даних.

Technical inventory is one of the main functions of real estate management and connects the formal and physical aspects of real estate. It consists in the fact that the information generated as a result of its implementation is necessary for further operations with the object: during the technical inventory of real estate, the indicators of the object are identified and officially fixed, which allows to unambiguously distinguish it from other objects. real estate. Therefore, the technical inventory is the basis for ensuring the rights of the state and citizens in the process of real estate management, as well as the basis of property relations.

A number of the main problems facing the market have been identified, the following being particularly acute:

- the difficulty of verifying data on real estate rights created before 2012 and cases of forgery, loss and / or destruction of documents with data on property rights;

- imperfect regulation of works on technical inventory of certain real estate objects for which there is a request from customers (on the one hand) and duplication of data on real estate objects created by different specialists, which leads to unnecessary costs for customers (on the other hand).

In accordance with the two problems, ways to solve them are proposed, namely:

Implement a pilot project on digitization of preliminary materials of technical inventory of several settlements, districts and / or united territorial communities and decide on the feasibility of digitizing data on real estate and property rights to them, which are created and stored in the BTI until 01.01. 2013. 
Improve the procedure for conducting a technical inventory of individual real estate objects by conducting a study on the need for legal regulation.

Define a list of required data to be uploaded to public inventories and registers electronically.

Improve the procedure for recording the fact of destruction, destruction, demolition of a construction or real estate object and public access to such data to other users.

Ключові слова: технічна інвентаризачія, нерухоме майно, Бюро технічної інвентаризації, Сдина державна електронна система

Keywords: technical inventory, real estate, Bureau of technical inventory, Unified state electronic system

Технічна інвентаризація є одною 3 основних функцій управління нерухомістю i пов'язує формальну та фізичну сторони об'єкта нерухомості. Вона полягає в тому, що сформована внаслідок їі проведення інформація є необхідною для здійснення подальших операцій з об'єктом: під час технічної інвентаризації нерухомого майна виявляються та отримують офіційне закріплення показники об'єкта, що дозволяють однозначно виділити його 3 - поміж інших об'єктів нерухомості. Тому технічна інвентаризація є основою для забезпечення прав держави та громадян у процесі управління нерухомістю, а також $є$ основою майнових відносин.

Інвентаризаційна справа, матеріали технічної інвентаризації та технічні паспорти з 1 грудня 2021 року розроблятимуться з використанням Реєстру будівельної діяльності Єдиної державної електронної системи у сфері будівництва [1].

Технічну інвентаризацію об'єктів нерухомого майна (OHM) здійснюють у випадках [2]:

- необхідності прийняття до експлуатації нових об'єктів будівництва;

- необхідності проведення держреєстрації права власності на незавершений об'єкт будівництва;

- необхідності проведення держреєстрації права власності на ОНМ, що утворився завдяки поділу, об'єднанню або виділенню частки;

- на підставі винесеного судового рішення тощо.

Метою роботи є дослідження кола основних проблем в питанні проведення технічної інвентаризації ОНМ в сучасних умовах, з якими має справу ринок та запропонувати шляхи їх вирішення 3 використанням сучасних програм та засобів автоматизованої роботи з базами даних.

На сьогодні Інструкція про порядок проведення технічної інвентаризації є єдиним нормативно-правовим документом для проведення технічної інвентаризації нерухомого майна в Україні $[3,4,5]$. Відповідно 
до неї на кожний об'єкт нерухомого майна заводиться інвентарна справа та проводиться первинна технічна інвентаризація.

Відповідно до Закону України «Про технічну інвентаризацію об'єктів нерухомого майна» [6] технічна інвентаризація $є$ комплексом робіт для визначення складу, фактичної площі, об'єму, технічного стану та фізичного зносу об'єктів нерухомого майна з виготовленням відповідних документів. Згідно з [6] є первинна технічна інвентаризація (проводиться вперше) і поточна (встановлює зміни технічних або якісних характеристик ОНМ за певний період часу після первинної інвентаризації).

Досвід проведення обмірів об'єктів нерухомості по всьому світу досить різноманітний. Після проведення досліджень щодо цього питання [7], було виявлено, що результати обмірів за місцевими законами та правилами сильно відрізняються від правил деяких ринків або в рамках одного ринку між різними територіальними одиницями через виключення з обмірів площ лоджій, терас, балконів або включення внутрішніх садів, басейнів тощо.

Аналогічно відрізняються й спеціалісти 3 проведення технічної інвентаризації в різних країнах світу. В одних країнах цим займаються спеціалісти з вимірювання, яких винаймають лише для здійснення обмірів OHМ, а в інших - експерти з оцінки або розроблення поповерхових планів.

Саме через такі та інші розбіжності було обговорено на зустрічі у Світовому банку Міжнародної коаліції стандартів вимірювання майна (IPMSC) в травні 2013 року. Метою організації $є$ розроблення єдиних міжнародних стандартів обмірювання нерухомого майна, без яких обміри нерухомості виглядали по різному і відрізнялися один від одного.

Для залучення міжнародних інвесторів та сприянню гарних умов щодо ведення бізнесу, потрібно звернути увагу на світовий розвиток в питанні проведення технічної інвентаризації.

Авторами [2] було визначено ряд основних проблем, 3 якими має справу ринок, особливого гостро постають наступні:

- складність перевірки даних про права на нерухоме майно, які створені до 2012 року та випадки підроблення, втрати та/або знищення документів з даними про право власності;

- недосконале врегулювання робіт 3 проведення технічної інвентаризації окремих ОНМ щодо яких $є$ запит від замовників (з одного боку) та дублювання даних про об'єкти нерухомості, які створюються різними спеціалістами, що призводить до зайвих витрат замовників роботи (з іншого боку).

3 50-х років минулого століття реєстрація будинків відбувалась завдяки Бюро технічної інвентаризації (БТІ) виконавчих комітетів місцевих Рад депутатів трудящих. 31996 до 2002 року право власності на нерухоме майно реєструвалося комунальними підприємствами БТІ. 32003 до 2012 року комунальні БТІ (але не всі) для реєстрації права власності та 
інших речових прав на нерухоме майно починають використовувати електронний Реєстр прав власності на нерухоме майно, власником якого було Міністерство юстиції України.

Починаючи 31 січня 2013 року Законом України від 11.02.2010 № 1878-VI «Про внесення змін до Закону України «Про державну реєстрацію речових прав на нерухоме майно та їх обмежень» та інших законодавчих актів України» [8] комунальні БТІ були позбавлені повноважень 3 реєстрації речових прав на нерухоме майно. 3 цієї дати державна реєстрація речових прав на нерухоме майно здійснюється виключно шляхом внесення електронного запису до Державного реєстру речових прав на нерухоме майно. У різний час з 1 січня 2013 року до теперішнього часу державну реєстрацію речових прав на нерухоме майно здійснювали державні реєстратори прав на нерухоме майно реєстраційних служб територіальних органів Міністерства юстиції України (повноваження яких вже припинено), акредитовані суб'єкти (повноваження яких теж припинено), державні реєстратори прав на нерухоме майно виконавчих органів сільських, селищних та міських рад, Київської, Севастопольської міських, районних, районних у містах Києві та Севастополі державних адміністрацій та нотаріуси.

Найчастіше архівні матеріали з БТІ зберігаються відповідним чином та в них можна знайти інформацію попередніх періодів. 3 іншого боку, існують окремі випадки відсутності, втрати, пошкодження, знищення та/або підроблення матеріалів із даними про будинки, домоволодіння чи право власності на об'єкти нерухомого майна, які виникли у період з 50-х років минулого століття до 2012 року включно.

Регулювання поступово досягає поставленої мети, але в процесі прийняття та застосування інструменту регулювання суттєво змінились обставини.

Вирішення даної проблеми можливо досягти наступним шляхом:

1. Реалізувати пробний проєкт $з$ оцифрування попередніх матеріалів технічної інвентаризації декількох населених пунктів, районів та/або ОТГ: під час проведення такого проєкту відпрацювати технологію обліку ОНМ та зареєстрованих на них речових прав, дані про які зберігаються у комунальних БТІ, із виконанням наступних заходів:

- мінімізації кількості помилок, що виникають внаслідок створення електронних даних на основі паперових документів;

- порівняння, узгодження та ув'язки отриманих даних із даними Державного земельного кадастру, Державного реєстру речових прав на нерухоме майно та його невід'ємної архівної складової - Реєстру прав власності на нерухоме майно.

2. За результатами пілотного проєкту, прийняти рішення щодо доцільності оцифрування даних про ОНМ та речові права на них, які створені та зберігаються у БТІ до 01.01.2013 (дата передачі повноважень 3 
реєстрації речових прав від БТІ до державних реєстраторів прав на нерухоме майно реєстраційних служб територіальних органів Міністерства юстиції України).

Діючою Інструкцією з технічної інвентаризації об’єктів нерухомого майна $[3,4]$ не врегульовано вимоги стосовно проведення технічної інвентаризації наступних об'єктів:

- Транспортні споруди: автостради, вулиці та дороги; залізниці; злітно-посадкові смуги; мости, естакади, тунелі та метро; порти, канали, греблі та інші водні споруди.

- Трубопроводи, комунікації та лінії електропередачі: магістральні трубопроводи, комунікації та лінії електропередачі; місцеві трубопроводи та комунікації.

- Водні та водогосподарські споруди.

- Комплексні промислові споруди.

- Споруди спортивного або рекреаційного призначення.

Стосовно цих об'єктів часто виникають суперечки щодо права власності, умов експлуатації, ремонту або реконструкції.

Виконавці робіт $з$ технічної інвентаризації пропонують додавання у матеріали технічної інвентаризації вибірково (за бажанням замовника) таких об'єктів, як бойлери, кондиціонери, супутникові антени тощо.

Існує неоднозначне розуміння використання технічної інвентаризації окремих об'єктів нерухомості. Наприклад: існують випадки проведення технічної інвентаризації машиномісць не у складі будівель, а на відкритих паркувальних майданчиках, після чого технічний паспорт на таке машиномісце використовується для реєстрації речового права на нього. Виникає суперечка співставлення таких об'єктів та речових прав на них із даними про земельну ділянку. Якщо машиномісце розглядати за аналогією 3 приміщенням, конфлікту не має, але якщо машиномісце розглядати за аналогією з земельною ділянкою - виникає конфлікт.

Відсутність регулювання знищення та знесення об'єктів нерухомості утворює складнощі для технічних інвентаризаторів, працівників органів містобудування та архітектури, реєстраторів прав, яким потрібно фіксувати таку інформацію і припиняти майнові права на будинок та приміщення у ньому.

Також відсутній нормативний документ щодо визначення технічного стану нежитлових об'єктів під час проведення технічної інвентаризації (для житлових будинків застосовуються СОУ ЖКГ 75.1135077234.0015:2009 «Правила визначення фізичного зносу житлових будинків»).

Саме зараз обговорюються та розробляються проєкти нормативноправових та нормативних актів щодо врегулювання робіт 3 технічної інвентаризації всіх вище зазначених об’єктів. 
Але, з іншого боку, в інших галузях у результаті вишукувальних та господарських робіт також створюються масиви даних, аналогічних тим, що створюються за результатами технічної інвентаризації об'єктів нерухомості, тобто виникає проблема дублювання даних. А саме:

Виконавці робіт із технічної інвентаризації об'єктів благоустрою складають технічні паспорти з даними про об’єкти благоустрою території загального користування в межах населеного пункту. В інструкції 3 проведення технічної інвентаризації та паспортизації об'єктів благоустрою, що затверджена наказом Мінрегіонбуду від 29.10.2012 р. №5502, розписані дуже нечітко способи проведення та використання результатів такої інвентаризації.

Експерти з технічного обстеження будівель та споруд за результатами обстеження прийнятих в експлуатацію об'єктів формують паспорти об'єктів будівництва разом з даними про їх технічний стан згідно із статтею 39-2 Закону України «Про регулювання містобудівної діяльності». Але інформація про обсяг виконаних робіт цими фахівцями відсутня.

Інженери-землевпорядники під час розроблення землевпорядної документації формують дані про земельні ділянки та угіддя, до складу яких входять дані про будівлі та деякі споруди, наприклад: дороги, споруди транспортної інфраструктури та інженерних комунікацій, але через те, що дані про ці об'єкти не відображаються у відкритому доступі, їх обсяг та стан $є$ невизначеним відносно всієї території України.

Інженери-геодезисти на топографічних планах відображають дані про об'єкти нерухомості, дороги, огорожі, споруди інженерної інфраструктури. Саме зараз немає відкритого веб-ресурсу для обліку топографічних даних, а моніторинг актуальності топографічних матеріалів великого масштабу на національному рівні не проводиться.

Серед вище зазначених об'єктів загальнодержавна електронна інформаційна система створена тільки стосовно обліку земельних ділянок - Державний земельний кадастр. Зараз створюються також Електронна система та Національна інфраструктура геопросторових даних. Різноманітні електронні системи стосовно інших об'єктів існують на регіональному, місцевому й галузевому рівнях з різними правилами та вони не охоплюють в цілому території України. Утворення електронних систем на місцевих та галузевих рівнях у сукупності збільшує витрати коштів місцевих бюджетів на їх подальшу підтримку та витрати часу а також коштів користувачів на адаптацію до цих систем.

Виходячи з усього вище наведеного, проблема не вирішується через недоліки існуючих процедур імплементації.

Вирішення даної проблеми можливо досягнути наступним шляхом:

1. Врегулювати питання стосовно технічної інвентаризації, переглянувши вимоги до електронних даних про технічні відомості наступних об'єктів: 
- Транспортні споруди:

- Трубопроводи, комунікації та лінії електропередачі:

- Водні та водогосподарські споруди.

- Комплексні промислові споруди.

- Споруди спортивного або рекреаційного призначення.

2. Провести дослідження системи об'єктів промисловості та комплексів об'єктів нерухомості на предмет необхідності вдосконалення правового регулювання їх технічної інвентаризації.

3. Визначити перелік обов'язкових даних, які потрібно завантажувати до публічних кадастрів та реєстрів в електронному вигляді, та даних, які можливо визначити вибірково за бажанням замовника 3 урахуванням технологічних можливостей фахівців за різними спеціальностями.

Під час розроблення вимог до електронних даних про спеціалізовані об'єкти нерухомості та місцевості:

- залучати до роботи фахівців із різною спеціалізацію, які будують, обліковують, експлуатують, обстежують та ремонтують відповідні об'єкти;

- формулювати правила та вимоги щодо недопущення дублювання даних, забезпечення оприлюднення та доступу до даних, інформаційної взаємодії між кадастрами та реєстрами, у яких збираються відповідні дані.

4. Вдосконалити процедуру фіксування факту руйнування, знищення, знесення об'єкту будівництва чи об'єкту нерухомості та публічного доступу до таких даних іншим користувачам, оновлення цієї інформації у інших різноманітних реєстрах, Державному земельному кадастрі, базі топографічних даних, містобудівному кадастрі місцевого рівня тощо.

5. Більш чітко визначити можливість проведення технічної інвентаризації машиномісць, розташованих поза будівлями.

Висновки: відповідно до поставлених двох проблем, запропоновано шляхи їх вирішення, а саме:

Реалізувати пробний проєкт 3 оцифрування попередніх матеріалів технічної інвентаризації декількох населених пунктів, районів та/або ОТГ та прийняти рішення щодо доцільності оцифрування даних про об'єкти нерухомого майна та речові права на них, які створені та зберігаються у БТІ до 01.01.2013.

Вдосконалити процедуру проведення технічної інвентаризації окремих об'єктів нерухомого майна шляхом проведення дослідження на предмет необхідності правового регулювання.

Визначити перелік обов'язкових даних, які потрібно завантажувати до публічних кадастрів та реєстрів в електронному вигляді.

Вдосконалити процедуру фіксування факту руйнування, знищення, знесення об'єкту будівництва чи об'єкту нерухомості та публічного доступу до таких даних іншим користувачам. 


\section{Список використаної літератури}

1. Закон України «Про внесення змін до деяких законодавчих актів України щодо удосконалення порядку надання адміністративних послуг у сфері будівництва та створення Єдиної державної електронної системи у сфері будівництва» (Відомості Верховної Ради (ВВР), 2019, № 51, ст.377) [Електронний pecypc]. - Режим доступу: https://zakon.rada.gov.ua/laws/show/199-IX\#Text

2. Бардасова I. Зелена книга. Системний перегляд якості державного регулювання ринків. Технічна інвентаризація об’єктів нерухомого майна // I. Бардасова, О. Пілат, С. Середюк. - К.: Офіс електронного регулювання [Електронний ресурс]. - Режим доступу: https://cdn.regulation.gov.ua/9e/ea/a7/c6/regulation.gov.ua_GB\%20Construction\%20Tec $\mathrm{h} \% 20$ inventory.pdf.

3. Про затвердження Інструкції про порядок проведення технічної інвентаризації нерухомого майна: Наказ Мінрегіонбуду України від 10.07.2001 p. №582/5773 // База даних «Законодавство України» / ВР України. [Електронний pecypc]. - Режим доступу: http://zakon0.rada.gov.ua/laws/show/z0582-01.

4. Про затвердження Змін до Інструкції про порядок проведення технічної інвентаризації об'єктів нерухомого майна: наказ Мінрегіонбуду України від 28.12.2012 p. № 658 // База даних «Законодавство України» / ВР України. [Електронний ресурс]. - Режим доступу: http://zakon3.rada.gov.ua/laws/show/z221212

5. Нестеренко Г.Б. Історичні аспекти та особливості проведення технічної інвентаризації об'єктів нерухомого майна // Г.Б. Нестеренко / Вісник ХНАУ ім. В.В. Докучаєва. Серія «Економічні науки», 2017. - № 4. -С. 123-132. [Електронний ресурс]. http://visen.knau.kharkov.ua/uploads/visn_econom/2017/4/14.pdf.

6. Закон України «Про технічну інвентаризацію об'єктів нерухомого майна» від 05.07.2012 № 10286. [Електронний ресурс]. - Режим доступу: https://ips.ligazakon.net/document/view/j77xq00g?an=3\&ed=2012_07_30.

7. Residential Property Measurement Practice. Evidence from World Regions. RICS Research, 2016 [Електронний pecypc]. - Режим доступу: https://www.rics.org/globalassets/rics-website/media/knowledge/research/researchreports/residential-property-measurement-practice-evidence-from-world-regions-rics.pdf.

8. Закон України «Про внесення змін до Закону України «Про державну реєстрацію речових прав на нерухоме майно та їх обмежень» та інших законодавчих актів України \{Із змінами, внесеними згідно із Законами № 4152-VI ( 4152-17 ) від 09.12.2011, ВВР, 2012, N 29, ст.331, №5037-VI ( 5037-17 ) від 04.07.2012, ВBР, 2013, N 23, ст.224,№ 5245-VI (5245-17 ) від 06.09.2012, ВВР, 2013, $\mathrm{N} 36$, ст.472\} [Електронний ресурс]. - Режим доступу: https://zakon.rada.gov.ua/laws/show/1878-17\#Text. 


\section{References}

1. Zakon Ukrainy «Pro vnesennia zmin do deiakykh zakonodavchykh aktiv Ukrainy shchodo udoskonalennia poriadku nadannia administratyvnykh posluh u sferi budivnytstva ta stvorennia Yedynoi derzhavnoi elektronnoi systemy u sferi budivnytstva» (Vidomosti Verkhovnoi Rady (VVR), 2019, № 51, st.377) [Elektronnyi resurs]. - Rezhym dostupu: https://zakon.rada.gov.ua/laws/show/199-IX\#Text

2. Bardasova I. Zelena knyha. Systemnyi perehliad yakosti derzhavnoho rehuliuvannia rynkiv. Tekhnichna inventaryzatsiia obiektiv nerukhomoho maina // I. Bardasova, O. Pilat, S. Serediuk. - K.: Ofis elektronnoho rehuliuvannia [Elektronnyi resurs]. $\quad-\quad$ Rezhym dostupu: https://cdn.regulation.gov.ua/9e/ea/a7/c6/regulation.gov.ua_GB\%20Construction\%20Tec h\%20inventory.pdf.

3. Pro zatverdzhennia Instruktsii pro poriadok provedennia tekhnichnoi inventaryzatsii nerukhomoho maina: Nakaz Minrehionbudu Ukrainy vid 10.07.2001 r. №582/5773 // Baza danykh «Zakonodavstvo Ukrainy» / VR Ukrainy. [Elektronnyi resurs]. - Rezhym dostupu: http://zakon0.rada.gov.ua/laws/show/z0582-01.

4. Pro zatverdzhennia Zmin do Instruktsii pro poriadok provedennia tekhnichnoi inventaryzatsii obiektiv nerukhomoho maina: nakaz Minrehionbudu Ukrainy vid 28.12.2012 r. № 658 // Baza danykh «Zakonodavstvo Ukrainy»/ VR Ukrainy. [Elektronnyi resurs]. - Rezhym dostupu: http://zakon3.rada.gov.ua/laws/show/z2212-12

5. Nesterenko H.B. Istorychni aspekty ta osoblyvosti provedennia tekhnichnoi inventaryzatsii obiektiv nerukhomoho maina // H.B. Nesterenko / Visnyk KhNAU im. V.V. Dokuchaieva. Seriia «Ekonomichni nauky», 2017. - № 4. -S. 123-132. [Elektronnyi resurs].

Rezhym dostupu:http://visen.knau.kharkov.ua/uploads/visn_econom/2017/4/14.pdf.

6. Zakon Ukrainy «Pro tekhnichnu inventaryzatsiiu obiektiv nerukhomoho maina» vid 05.07.2012 № 10286. [Elektronnyi resurs]. - Rezhym dostupu: https://ips.ligazakon.net/document/view/jf7xq00g?an=3\&ed=2012_07_30.

7. Residential Property Measurement Practice. Evidence from World Regions. RICS Research, 2016 [Elektronnyi resurs]. - Rezhym dostupu: https://www.rics.org/globalassets/rics-website/media/knowledge/research/researchreports/residential-property-measurement-practice-evidence-from-world-regions-rics.pdf.

8. Zakon Ukrainy «Pro vnesennia zmin do Zakonu Ukrainy «Pro derzhavnu reiestratsiiu rechovykh prav na nerukhome maino ta yikh obmezhen» ta inshykh zakonodavchykh aktiv Ukrainy \{Iz zminamy, vnesenymy zghidno iz Zakonamy № 4152VI ( 4152-17 ) vid 09.12.2011, VVR, 2012, N 29, st.331, №5037-VI ( 5037-17 ) vid 04.07.2012, VVR, 2013, N 23, st.224,№ 5245-VI (5245-17 ) vid 06.09.2012, VVR, 2013, N 36, st.472\} [Elektronnyi resurs]. - Rezhym dostupu: https://zakon.rada.gov.ua/laws/show/1878-17\#Text. 